\title{
IMPROVING VOCABULARY MASTERY USING PICTURE FOR SECOND GRADE STUDENTS AT SLB- C TUT WURI HANDAYANI
}

\author{
Pipit Pitria Handayani' ${ }^{1}$ Imam Muddin² \\ ${ }^{1}$ IKIP Siliwangi \\ ${ }^{2}$ IKIP Siliwangi \\ 11pipitpitria2512@gmail.com, ${ }^{2}$ muddinimam21@gmail.com,
}

\begin{abstract}
Communication is always needed in the lifes of human. The human communicate using different language. The language used always has vocabulary to understand. So, the communication can ocuur well. The vocabulary of language is a basis in learning language, includes English as foreign language in Indonesia that learnt by students elementary school untill University. Learning vocabulary of language is not easy especially for the students who has mental retardation. It was proved by the observation at Second Grade of SLB C Tut Wuri handayani that shows that they are low to memorize and difficult to say the vocabulary of English. To solve the problem, the writer conducted the research by using picture media to improve student's vocabulary mastery. This research used qualitative research design with Classroom Action Research Method. The sample of this reearch was 5 students at second grade. The instrument used was observation then the data collection and analysis was observation. The result of this research shows that the student's vocabulary mastery in learning english towards Mental retadartion students at SLB- C Tut Wuri Handayani was improved.
\end{abstract}

Keywords: Vocabulary, Picture Media

\section{INTRODUCTION}

As social beings, humans are not be able to live in their life without socialization with others, thus they have to do an activity which is called "communication". The term of communication can be defined as how the humans interact to others. Language is needed when the human communicate, weather commonication using first language or foreign language. In the communication using language, vocabulary becomes basis part of language. So, vocabulary is imprtant thing in a language, beause with the vocabulary of language, the communication can be understood.

According to Aitchison \& Lewis (2004) vocabulary is a set of words known to a person or other eternity, or that are parts of specific language. In addition, vocabulary is an essential part in learning language, includes foreign language. In indonesia, English is foreign language that learnt from elementary school until University. Furthermore, learning vocabulary is not easy 
for the students because they have to know the meaning and memorize of new words. Some students may have strong memory, but other students may have low memory. Learning vocabulary will be harder when the students have special needs. According to Dr, Bandi, \& Delphie (2006), the children with special needs is another term to replace the word extraordinary child which indicates the existence of special abnormalities that have characteristics different from one another. The observation at SLB C Tut Wuri Handayani showed that learning vocabulary is harder for the teacher because it has students Mental Retardation. The students are low to memorize and difficult to say the vocabulary of English. To solve the problem, the teacher can use the media to improve their skill in learning vocabulary. According to Brown (2007) by using media, the students will be active in learning and the teacher will enjoy the evidence of their progress. One of media that can be used by teacher is picture. Meanwhile, Wright, n.d.) states that pictures are very important in helping students to retell expreriences or understand something since they can represent place, object, people, etc, so that the students can memorize the words related to the picture.

Based on explanation of the problem, the writer conducted the research at SLB-C Tut Wuri Handayani with the research questions: How picture media improves student's vocabulary in learning English?

\section{METHOD}

In this research, the writer used qualitative research design. According to Creswell (2013) qualitative research is an approach to explore and understand the meaning of individuals or groups that are perceived as a social or human problem. The research method of this research was CAR (Classroom Action Research). The design of CAR according to Suharsimi (2010) can be seen in the following:

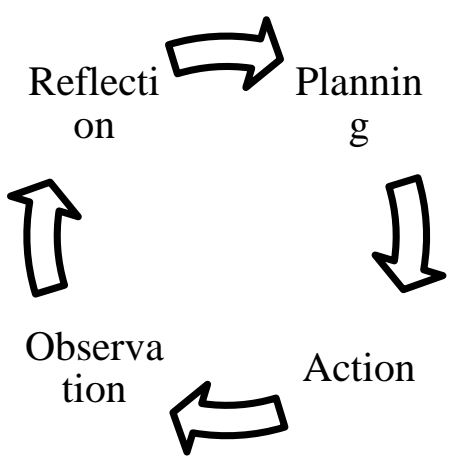

\section{Figure 1. Design of Classroom Action Research}

Based the figure above, in conducting this research the writer did four steps in a cycle:

1. Planning : planning the steps in teaching vocabulary using picture media

2. Action : Acting the palns that has been done

3. Observation : Observing the result of the action

4. Reflection : Reflecting by analysis the result of the observation to find out the 
weakness and improve it.

The population of this research was second grades at SLB C Tut Wuri Handayani and the sample was second grade of $\mathrm{C}$ with total of students are 5 students. Furthermore the instrument used in this research was obserrvation. In accordance with the instrument, in collecting and analysis data of this research, the writer observation method.

\section{RESULTS AND DISCUSSION}

\section{Results}

In the resut, the research carried on the second grade at SLB C Tut Wuri Handayani for 8 meetings. The eight meetings were categorized into 2 cycles. The result of each cycle will be organized on four steps of CAR, namely : (1) planning, (2) acting, (3) observing, and (4) reflecting.

The steps of acting and observing are displayed on table 1 below :

Table 1. Meetings in Cycle 1

\begin{tabular}{|c|c|c|}
\hline \multicolumn{2}{|l|}{ Acting } & Observing \\
\hline Meeting & Topic & Activity \\
\hline 1 & $\begin{array}{l}\text { Practice } 1 \text { : } \\
\text { Show the picture about animals and } \\
\text { give the general questions. }\end{array}$ & $\begin{array}{l}\text { In this first meeting, the } \\
\text { researchers give them a pre-test } \\
\text { which consist of } 5 \text { words (name of } \\
\text { animals) }\end{array}$ \\
\hline 2 & $\begin{array}{l}\text { Treatment } 1: \\
\text { Name of animals using picture. }\end{array}$ & $\begin{array}{l}\text { The students interested about the } \\
\text { material one by one. Students learn } \\
\text { the material with some visual } \\
\text { media and make them easy to } \\
\text { remember the material. }\end{array}$ \\
\hline 3 & $\begin{array}{l}\text { Treatment } 2 \text { : } \\
\text { General questions such as "what is } \\
\text { this?", "do you have this animal in } \\
\text { your house?", "that is __,, "yes / } \\
\text { no". }\end{array}$ & $\begin{array}{l}\text { In this meeting, students try to } \\
\text { answer the questions with the new } \\
\text { vocabullay such as have or name of } \\
\text { animals. Students try to write the } \\
\text { new vocabullary in they book. } \\
\text { Students do this activity using } \\
\text { picture and matching word }\end{array}$ \\
\hline 4 & $\begin{array}{l}\text { Practice } 2 \text { : } \\
\text { Show the picture about animals and } \\
\text { give the general questions. }\end{array}$ & $\begin{array}{l}\text { In this meeting, the researchers } \\
\text { conducted post-test which consists } \\
\text { of } 5 \text { words (names of animals). The } \\
\text { questions presented in the same } \\
\text { form and level of difficulty with } \\
\text { the pre-test. }\end{array}$ \\
\hline
\end{tabular}

Based on treatment 1, students looked confused and they did not understand the material. Students did not know how to start and how to do. But in the end of treatment, children with 
special needs feel a little understand about how to learn English vocabulary using picture media, however students were still confused and forgot about name of animals. In this treatment, the researchers should be patient to face them because students were easy to forget and were hard to understand the material. From these cycle 1, the researchers can draw a conclusion during a lesson. The positive of this cycle is students can try to practice, and write the new vocabulary. The negative of this cycle, some of students were still passive since they have different level of intellectual disability.

Therefore, the cycle II was carried out to continue the research in table 2.

Table 2 Meetings in cycle 2

\begin{tabular}{|l|l|l|}
\hline Acting & Topic & Observing \\
\hline 5 & $\begin{array}{l}\text { Treatment 3: } \\
\text { Name of animal and ability using } \\
\text { picture. }\end{array}$ & $\begin{array}{l}\text { The researchers continued the material } \\
\text { to make students more understanding. } \\
\text { Repeat and repeat again in this learning } \\
\text { process. Using picture to remmember } \\
\text { the name of animals and ability. }\end{array}$ \\
\hline 6 & $\begin{array}{l}\text { Treatment 4: } \\
\text { General questions such as "what is } \\
\text { this?", "do you have this animal in } \\
\text { your house?", "that is _", "yes } \\
\text { / no". }\end{array}$ & $\begin{array}{l}\text { On this treatment, students play a game } \\
\text { using picture media. Repeat the materail } \\
\text { that have discussed before on treatment } \\
\text { 2. Students really need repetation. As } \\
\text { students can feel enthusiasm and } \\
\text { interested to learn English vocabulary. }\end{array}$ \\
\hline 7 & $\begin{array}{l}\text { Practice 3: } \\
\text { Show the picture about animals } \\
\text { and give the general questions. }\end{array}$ & $\begin{array}{l}\text { In this meeting, the researchers } \\
\text { conducted post-test which consists of 5 } \\
\text { words (names of animals). The } \\
\text { questions presented in the same form } \\
\text { and level of difficulty with the pre-test. }\end{array}$ \\
\hline
\end{tabular}

Reflecting of the observation done would be discussed in this section. From activity 1 and activity 2 students interest has increased in learning English vocabulary. Students more easy to remember because they say usually repeat the words. We can seen the improvement on attitude and behaviour by table 3 .

Table 3. Improvement on attitude and behaviour.

\begin{tabular}{|l|l|l|}
\hline Name & Points & Improvements \\
\hline \multirow{3}{*}{ Student A } & Activeness & $\begin{array}{l}\text { The students seemed more action in learning process. Student } \\
\text { try to ask some questions to the reseracher and active in } \\
\text { learning process. }\end{array}$ \\
\cline { 2 - 3 } & Anthusiasm & $\begin{array}{l}\text { the students became very enthusiastic about the English lesson } \\
\text { because the researcher used a method that attracted the } \\
\text { attention of the students by using picture meda. }\end{array}$ \\
\hline
\end{tabular}




\begin{tabular}{|c|c|c|}
\hline & Interested & $\begin{array}{l}\text { the students are interested in the English vocabulary because } \\
\text { the researchers use media that helps students to memorize word } \\
\text { for word using picture. }\end{array}$ \\
\hline \multirow{3}{*}{ Student B } & Activeness & $\begin{array}{l}\text { The students seemed more action in learning process. They try } \\
\text { to ask some questions to the reseracher. }\end{array}$ \\
\hline & Anthusiasm & $\begin{array}{l}\text { the students became very enthusiastic about the English lesson } \\
\text { because the researcher used a method that attracted the } \\
\text { attention of the students by using picture meda. }\end{array}$ \\
\hline & Interested & $\begin{array}{l}\text { the students are interested in the English vocabulary because } \\
\text { the researchers use media that helps students to memorize word } \\
\text { for word using picture. }\end{array}$ \\
\hline \multirow{3}{*}{ Student C } & Activeness & $\begin{array}{l}\text { The students seemed more action in learning process. They try } \\
\text { to ask some questions to the reseracher. }\end{array}$ \\
\hline & Anthusiasm & $\begin{array}{l}\text { the students became very enthusiastic about the English lesson } \\
\text { because the researcher used a method that attracted the } \\
\text { attention of the students by using picture meda. }\end{array}$ \\
\hline & Interested & $\begin{array}{l}\text { the students are interested in the English vocabulary because } \\
\text { the researchers use media that helps students to memorize word } \\
\text { for word using picture. }\end{array}$ \\
\hline Student D & Activeness & $\begin{array}{l}\text { The students seemed more action in learning process. They try } \\
\text { to ask some questions to the reseracher. But the student D less } \\
\text { anthusiasm and interest in learning process. }\end{array}$ \\
\hline \multirow[b]{2}{*}{ Student E } & Anthusiasm & $\begin{array}{l}\text { the students became very enthusiastic about the English lesson } \\
\text { because the researcher used a method that attracted the } \\
\text { attention of the students by using picture meda. }\end{array}$ \\
\hline & Interested & $\begin{array}{l}\text { the students are interested in the English vocabulary because } \\
\text { the researchers use media that helps students to memorize word } \\
\text { for word using picture but the student E not Active in learning } \\
\text { process. }\end{array}$ \\
\hline
\end{tabular}

Based on the table 3 above, the writer concluded that the students improved in activeness, anthusiasm and interested of using picture as media in teaching process.

\section{Discussion}

Based on the cycle 1, the writer find out that the students can try practice new vocabulary however some of students were still passive because they have different level of intelectual disability. So the cycle 2 was needed in this research. Meanwhile, in the result of cycle 2, the skill of students improve. It can be seen from the students who more easy to remember because they usually say the words repeatly. In addition, the improvement of attitude and behaviour was increased, it can be seen from the improvement of students in activeness, anthusiasm and interest. So, in the end of the research concluded that the use of picture media improved student's vocabulary mastery. 


\section{CONCLUSION}

Based on the result and the discussion, the writer concluded that the picture media can improve students' especially in learning english vocabulary to Mental retadartion students' at SLB- C Tut Wuri Handayani.

\section{ACKNOWLEDGMENTS}

Praise god almighty, for the presence of plenty of mercyand his grace, so that the researchers can complete the thesis with the title : improving vocabulary mastery using picture for second grade students' at SLB-C Tut Wuri Handayani.

\section{REFERENCES}

Aitchison, J., \& Lewis, D. M. (2004). New media language. New Media Language. london and newyork: Routledge. https://doi.org/10.4324/9780203696965

Brown, D. H. (2007). First Language Acquisition, Principles of Language Learning and Teaching. Pearson ESL. Pgs. Retrieved from http://cmmr.usc.edu/543/Brown_First_Language_Acquisition.PDF

Creswell, J. (2013). Research Design : Pendekatan Kualitatif, Kuantitatif, dan MIxed. Research design. https://doi.org/10.2307/3152153

Dr, Bandi, \& Delphie, M. A. (2006). BAB II KAJIAN PUSTAKA. Bandung: PT. Refika Aditama, (3). Retrieved from http://digilib.uinsby.ac.id/8635/3/bab 2.pdf

Suharsimi, A. (2010). Prosedur Penelitian: Suatu Pendekatan Praktik (Edisi Revisi). Jakarta: Rineka Cipta (Vol. 1). https://doi.org/10.1017/CBO9781107415324.004

Wright, A. (n.d.). Picture for Language Leaning. Cambridge University Press. 